\title{
Joy and Flustration with Organofluorine Compounds - A Fluorous Autobiography
}

\author{
Dieter Seebach* \\ Dedicated to the memory of Professor Manfred Schlosser, great chemist, friend and fellow lover of \\ fluoro-organic chemistry ${ }^{[1]}$
}

\begin{abstract}
An overview is given about our work on fluoro-organic compounds, published or described in $\mathrm{PhD}$ theses between 1977 and 2013. After a discussion of structural F-effects and F-tagging applications the material is ordered by the various areas of our research, in which we have used and/or prepared F-derivatives: Li- and Tiorganic compounds and reagents, polylithiated hydroxy-esters and nitroalkanes, the enantiopure trifluoro-lactic, -Roche, and -3-hydroxy-butanoic acids as toolbox for the preparation of numerous $\mathrm{F}_{3} \mathrm{C}$-substituted compounds, including natural products and dendrimers, and fluoro- $\alpha-,-\beta-$, and $-\delta$-amino acids, as well as peptides with back-bond-bound fluorine. The strong influence on $\beta$-peptide folding by fluoro-substituents in the $\alpha$-position of $\beta$-amino-acid residues is discussed in terms of the $\alpha$-fluoro-amide conformational effect. Finally, some cases of totally unexpected effects on reactivity and structure exerted by fluoro-substitution are presented and taken as examples for our use of the terms flustrate and flustration in connection with organo-fluorine chemistry.
\end{abstract}

Keywords: $\mathrm{CF}_{3}$-substituted dendrimers - Enantiopure aliphatic $\mathrm{CF}_{3}$-derivatives $\cdot \mathrm{F}$-effects on peptide folding . F-labelling and tagging · Fluoro-organic compounds

\section{Introduction}

When I was invited to contribute an article to the topical CHIMIA issue on organofluorine chemistry I was brave enough to accept, without realizing how many papers had been published by us in this area ${ }^{[2-41]}$ over the past $3 \frac{1}{2}$ decades, and how many $\mathrm{PhD}$ theses had been devoted more or less entirely to this topic in my group: ${ }^{[42-48]}$ it turns out that throughout my career as a methodologically oriented synthetic organic chemist fluorine derivatives exerted an irresistible attraction on me. Fluorine appears in every period of research activities my group had entered: organo-sulfur, organo-lithium, organo-titanium, and nitroorganic chemistry, enzymes as catalysts, electrochemistry, amino-acid and peptide chemistry, dendrimers, the biopolymer PHB, self-regeneration of stereocenters, [-(Arl) ${ }_{2} \mathrm{C}-\mathrm{O}-{ }_{-}$-groups ${ }^{[49]}$ in organic synthesis, and organocatalysis. In order to provide a representative overview, I decided

${ }^{*}$ Correspondence: Prof. Dr. D. Seebach Eidgenössische Technische Hochschule Zürich Departement für Chemie und Angewandte

Biowissenschaften (D-CHAB)

Laboratorium für Organische Chemie

$\mathrm{HCl} \mathrm{H} 331$

Vladimir-Prelog-Weg 3

$\mathrm{CH}-8093$ Zürich

E-mail: Seebach@org.chem.ethz.ch to prepare a kind of collage of schemes and figures, with a minimum of text and complete referencing; most of the formulae, diagrams and pictures shown here are actually copied from our corresponding papers. Work of other groups on the same subjects is referred to in our publications and the$\operatorname{ses}^{[2-48]}$ and will not be cited herein. Also, with few exceptions, no effort is made to update the literature in the various fields. Thus, a very personal fluorous autobiography is presented.

\section{Structural Fluorine Effects and Fluorine as Tagging Element}

Fluorine, the most electronegative element, exerts a strong generalized gaucheeffect, which, in the examples shown in Fig. 1a, can be discussed in terms of anomeric $n_{\mathrm{N}} \rightarrow \sigma^{*}{ }_{\mathrm{C}, \mathrm{F}}$ or $\sigma_{\mathrm{C}, \mathrm{H}} \rightarrow \sigma^{*}{ }_{\mathrm{C}, \mathrm{F}}$ interactions. ${ }^{[53]}$ On the other hand, in $\alpha$-fluoroamides the ap-conformation of the $(\mathrm{C}, \mathrm{F})$ and the $(\mathrm{C}, \mathrm{O})$-bond is strongly favored, an effect that can dominate the structure of F-substituted $\beta$-peptides (vide infra). - In spite of the big electronegativity difference between $\mathrm{C}$ and $\mathrm{F}$ and thus polarity of the C,F-bond "organic fluorine hardly ever accepts hydrogen bonds". ${ }^{[54]}$ The still widely taken views that $\mathrm{F}$ is a substitute of $\mathrm{OH}$ as a hydrogen-bond acceptor, and that $\mathrm{F}$ is just a "big hydrogen" are wrong (the A-value of $F$ is 0.15 ) (Fig. $1 \mathrm{~b}-\mathrm{d}$ ).

The magnetic nucleus ${ }^{19} \mathrm{~F} \quad(100 \%$ abundance) provides unique probes for detection of organofluorine compounds by NMR (and ESR) spectroscopy, and ${ }^{18} \mathrm{~F}$-derivatives are widely used for PET diagnosis. We have used F-tagging for detection and identification of (RS) ${ }_{3} C^{\cdot}$ radicals and of fluoro-carbenoides (Fig. 2). Introduction of $\mathrm{F}_{3} \mathrm{C}$-groups into oligo( $\beta$ hydroxybutyrates) and into $\beta$-peptides consisting of 2,2-dimethyl-3-amino-propanoic acid residues was used for obtaining information about the oligomer-backbone structures, also of dendrimers (vide infra). Labeling coenzyme A with an $\mathrm{F}_{3} \mathrm{C}$-group gave a valuable NMR probe for studying biochemical processes (Fig. 2). Finally, we have also used the so-called fluorous tagging strategy, ${ }^{[55]}$ which exploits the affinity of fluorocarbons for each other ( $c f$. the non miscibility of $\mathrm{C}_{n} \mathrm{H}_{2 n+2}$ and $\mathrm{C}_{n} \mathrm{~F}_{2 n+2}{ }^{[56]}$ ), for peptide synthesis in a microreactor (Fig. 2).

\section{Fluorine-containing Organo-Ti- and Organo-Li-reagents}

When we turned from organolithium to the much more selective organotitanium reagents ${ }^{[57]}$ in the early 1980 s, which was also the period of invention of the TADDOLs ${ }^{[49]}$ we discovered that 2-fluorophenyl titanium compounds are stable at room temperature (Fig. 3) and could be used for highly selective carbonyl additions. 
a)<smiles>[X]C1CCC2CC1CC2F</smiles><smiles>CNCF</smiles><smiles>C#CC#CC</smiles><smiles>CNC(=O)C(C)(C)F</smiles>

b)

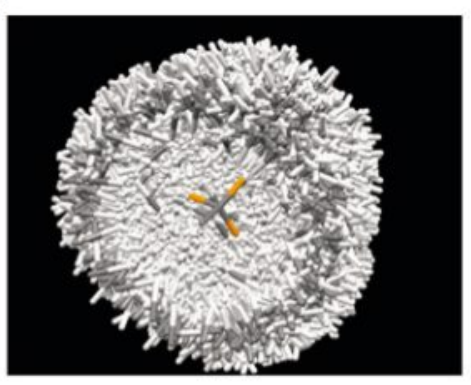

c)
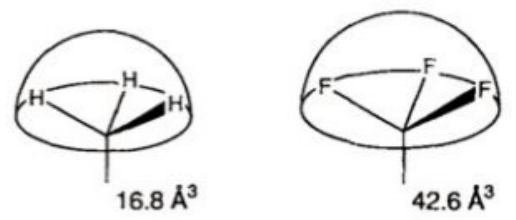

[14] energy difference
$[$ Kcal/mol]<smiles>[X]C1CCCCC1F</smiles>

$-1 \quad(\mathrm{X}=\mathrm{F})$

$-4.4(\mathrm{X}=\mathrm{OMe})$

$-5.8\left(X=\mathrm{NH}_{3}{ }^{+}\right)$<smiles>NC([O-])F</smiles>

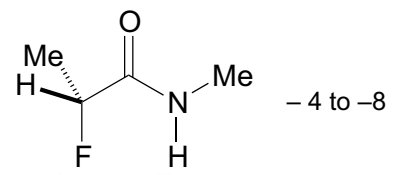

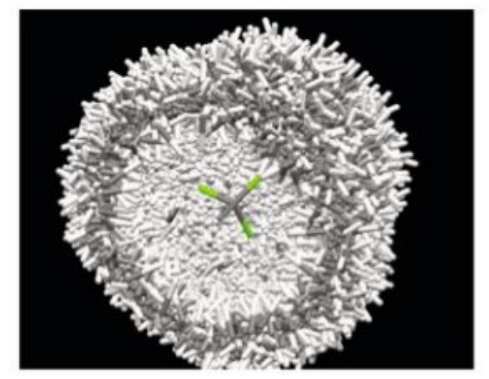

d)

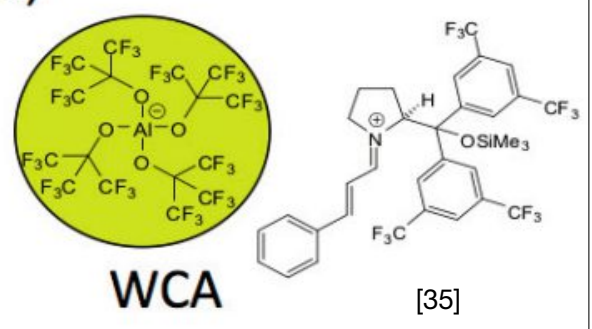

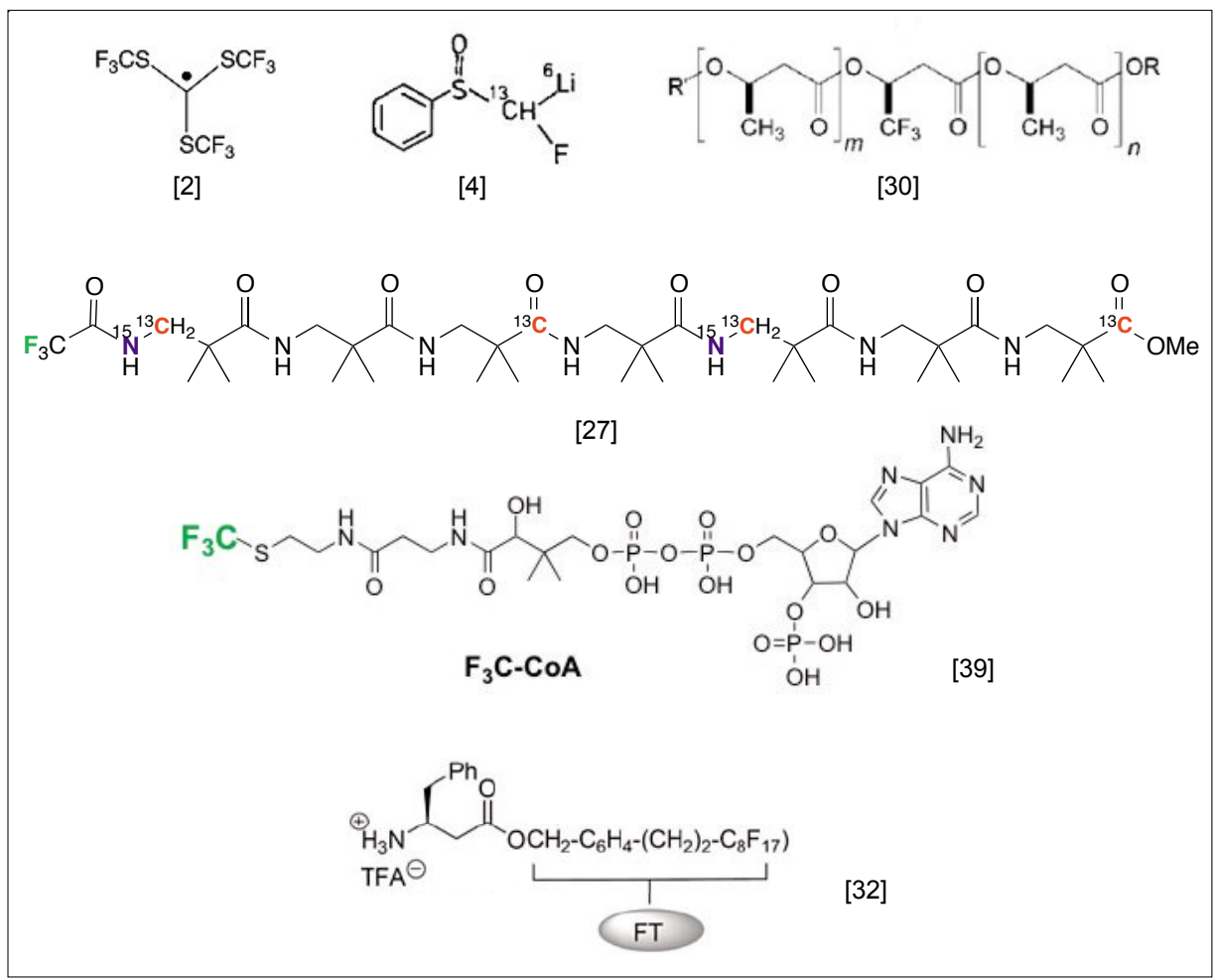

Fig. 1. Structural effects of fluorine. a) gaucheEffect in $\mathrm{X}-\mathrm{CH}_{2}-\mathrm{CH}_{2}-\mathrm{F}$ and ap-effect in $\alpha$-fluoroamides; the energy differences have been determined experimentally and/or computationally. ${ }^{[3,50]}$ b) Next hydrogen neighbors to $\mathrm{CH}_{3}$ (left) and $\mathrm{F}_{3} \mathrm{C}$ (right); an overlay of ca. $2500 \mathrm{X}$-ray structures each, found in the CSD data base in June 2010, using the CCDC Software Isostar (version Nov. 2009), ${ }^{51]}$ a library of information about non-bonded interactions; in this respect, there is no indication of a fundamental difference between $\mathrm{CH}_{3}$ and $\mathrm{F}_{3} \mathrm{C}$, except that $\mathrm{F}_{3} \mathrm{C}$ is much larger than $\mathrm{CH}_{3}{ }^{{ }^{352]}} \mathrm{C}$ ) van-der-Waals volume of $\mathrm{CH}_{3}$ and $\mathrm{F}_{3} \mathrm{C} ;[$; 14$]$ the latter has approximately the same volume as an isopropyl group. d) Perfluoro tetra-tbutoxy-aluminate, a weekly or non-coordinating anion (WCA, NCA) for crystallization and $\mathrm{X}$-ray structure determinations ${ }^{[35]}$ - a big ball covered by $F$ atoms with a negatively charged core, engaging in no interactions with the cation.

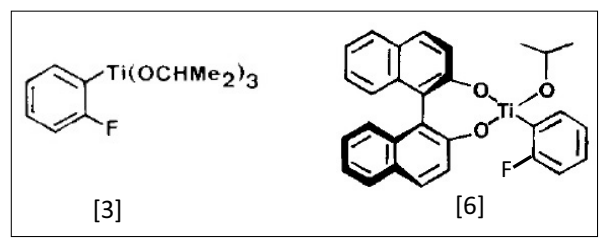

Fig. 3. ortho-Fluorophenyl-titanium derivatives. Unlike ortho-fluoro-phenyllithium, which is subject to $\beta$-elimination and dehydro-benzene formation, the triisopropoxy-titanium analog is stable at room temperature (colorless powder under inert atmosphere). ${ }^{[3]}$ Enantioselective additions to carbonyl compounds have been achieved with the binol derivative. ${ }^{[6]}$ The stability of such compounds is especially surprising when we consider the high Ti,F-affinity (virtual $\mathrm{Ti}-\mathrm{F}$ bond energy $136 \mathrm{Kcal} / \mathrm{mol}$ ).

Our long-lasting interest in nitroorganic compounds ${ }^{[58]}$ led to an investigation of di- and trifluoro-nitroethane and trifluoro-2-nitro-propane (Fig. 4), which were generously supplied to us by the Bayer company. Like the non-fluorinated analogs, the di- and trifluoro-nitroalkanes could be $\alpha, \alpha$-doubly deprotonated (to 'supernitronates') or $\alpha, \beta$-doubly deprotonated (to 'superenamines'), to give reagents that add to aldehydes and ketones and to $\alpha, \beta$-unsaturated carbonyl derivatives. By $\mathrm{NO}_{2}$ reduction the corresponding amino compounds are accessible (Fig. 4).

Fig. 2. Use of fluorine tagging. Detection of $\mathrm{C}, \mathrm{C}-$ dissociation of $(\mathrm{RS})_{3} \mathrm{C}-\mathrm{C}(\mathrm{SR})_{3}$; a Li-carbenoid with three magnetic labels; $\mathrm{F}_{3} \mathrm{C}$-analogs of $\mathrm{PHB}$ for structural investigations by means of solidstate ${ }^{19} \mathrm{~F}-\mathrm{NMR}$ techniques; a $\beta$-heptapeptide with ${ }^{19} \mathrm{~F},{ }^{15} \mathrm{~N}$ and ${ }^{13} \mathrm{C}$ labeling for TEDOR/REDOR NMR analysis of the solid-state structure; $\mathrm{F}_{3} \mathrm{C}$ CoA as NMR probe for studying intermolecular chain translocation in ketosynthase; fluorous tagging of $\mathrm{H}-\beta^{3} \mathrm{hPhe-benzyl} \mathrm{ester,} \mathrm{causing} \mathrm{solu-}$ bilization and ease of purification (on fluorous silica gel) in $\beta$-peptide synthesis carried out in a microreactor. 


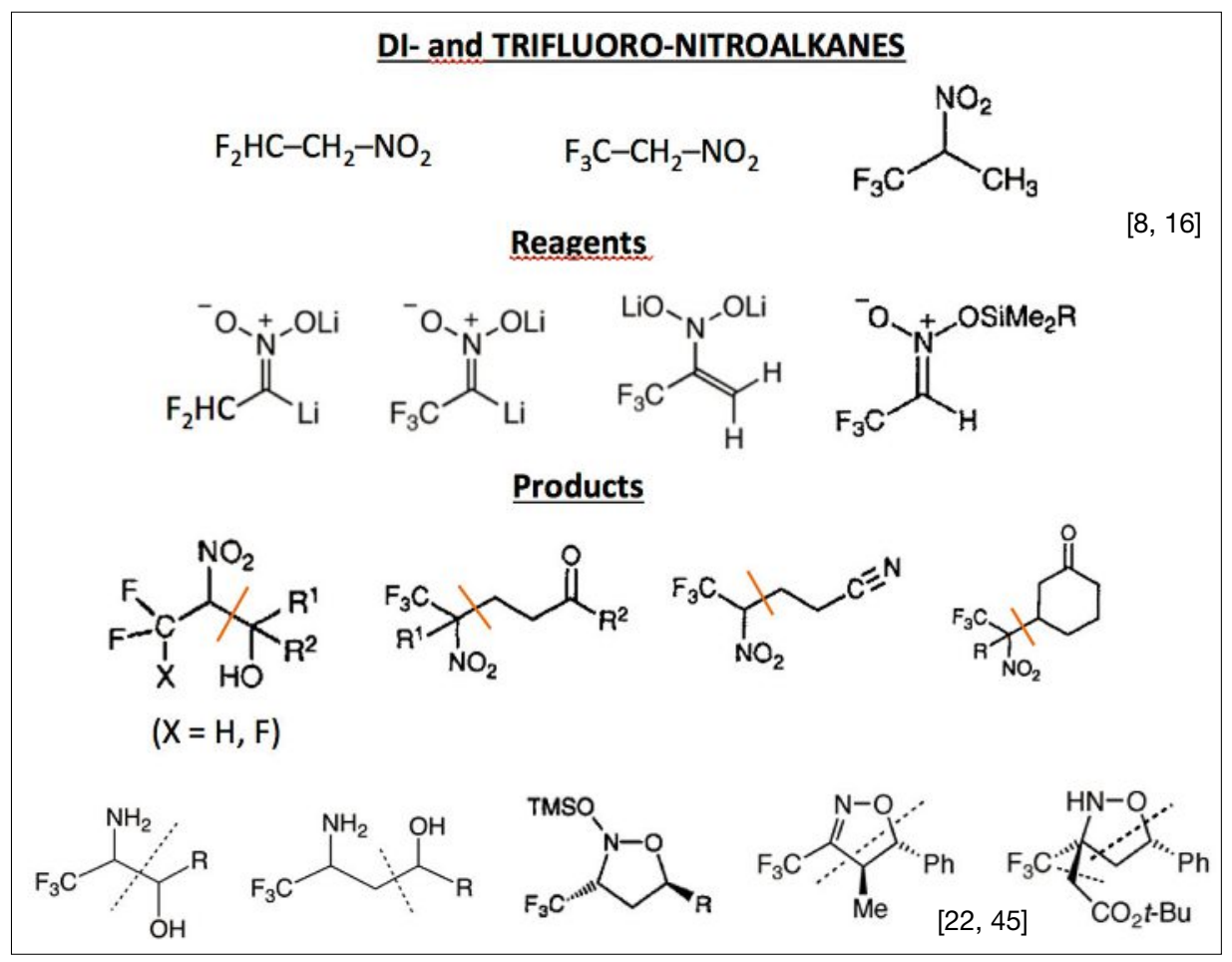

\section{Enantiopure Trifluoro-hydroxy- acids Providing a Toolbox for the Preparation of $\mathrm{F}_{3} \mathrm{C}$-Derivatives}

Besides carbohydrates and amino acids, the simple hydroxy acids lactic acid, malic acid, 3-hydroxy-butanoic acid, 3-hydroxy-2-methyl-propanoic acid (Rocheacid), tartaric acid, and mandelic acid are cheap and readily available enantiopure starting materials (pool of chiral building blocks or 'chiral pool') for organic synthesis. There is a rich body of publications describing elaborations of these chiral compounds to a myriad of products (for reviews from our group see ref. [59]), in many cases this 'source of chirality' is a viable alternative of enantioselective trans-
Fig. 4. Doubly deprotonated di- and trifluoronitroalkanes and trifluoro-silylnitronates as nucleophiles and for 1,3-dipolar cycloadditions. Surprisingly, there is no fluoride elimination (at low temperatures) from the dilithio derivatives and no F,Si-formation from the silylnitronate (bond energy Li-F and Si-F 138 and $129 \mathrm{Kcal} /$ mol, respectively!). 1,2-Additions, conjugate additions and 1,3-dipolar cycloadditions lead to a variety of $\mathrm{F}_{2} \mathrm{HC}$ - and $\mathrm{F}_{3} \mathrm{C}$-derivatives with additional functional groups.

formations. To make the corresponding trifluoro-derivatives also readily available, we have prepared trifluoro-latic (Fig. 5), trifluoro-Roche (Fig. 6) and trifluoro-hydroxy-butanoic acid (Figs. 7a,b,c) in both enantiomeric forms by large-scale resolutions and demonstrated their value as chiral starting materials and valuable building blocks (Figs. 5-7).

\section{Fluoro-substituted Amino Acids and Peptides}

Not surprisingly, fluorine also 'invaded' our work on amino acids and peptides. Thus, Li-enolates of the chiral, enantiopure glycine derivatives Boc-BMI, $\mathrm{Bz}-\mathrm{BMI}$, and 2-tBu-3-Cbz-oxazolidinone were alkylated with benzyl halides or added to aldehydes carrying fluoro- or $\mathrm{F}_{3} \mathrm{C}$-substituents (Fig. 8a). - The unique $\mathrm{C}_{9}$-amino acid of cyclosporins, Me-Bmt, was synthesized with stereoselective in-

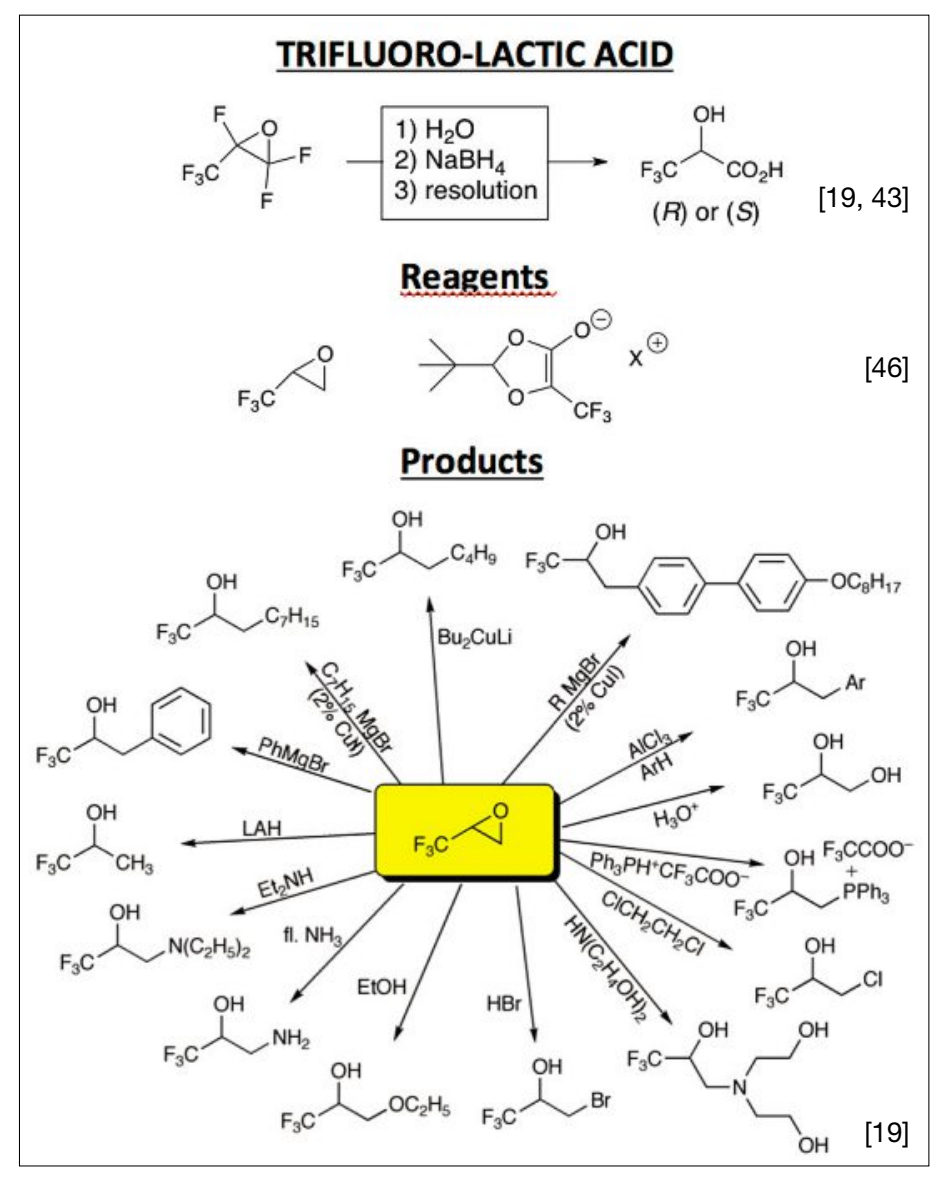

Fig. 5. (R)- and (S)-Trifluoro-lactic acid and trifluoromethyl-oxirane. Hydrolysis of perfluoro-propylene oxide (cheap monomer of a valuable polymer), reduction and resolution (with 2-amino-1-phenyl-1,3-propandiol) to $\mathrm{F}_{3} \mathrm{CCH}(\mathrm{OH}) \mathrm{CO}_{2} \mathrm{H}$, which is readily converted to the $\mathrm{F}_{3} \mathrm{C}$-oxirane, numerous reactions of which had been published by other groups (see the references in ref. [19]).

$$
\text { TRIFLUORO-ROCHE ACID }
$$

Fig. 6. (R)- and (S)-2-Trifluoromethyl-3-hydroxy-propanoic acid $\left(\mathrm{F}_{3}\right.$-Roche acid). Conversion of trifluoro-propene to the corresponding Roche acid and resolution (with 2-amino-1-phenyl-1,3-propanediol). The special feature of Roche acid (first recognized by the Hoffmann-La Roche chemist A. Fischli[60]) is its 'hidden' symmetry: from one of its enantiomers either enantiomer of a product is accessible by analogous elaborations on the two enantiotopic carbon atoms $\mathrm{C}(1)$ and $\mathrm{C}(3)$ (cf. $\mathrm{R}^{1} \mathrm{O}-\mathrm{CH}_{2}-\mathrm{CHCH}_{3}-\mathrm{CH}_{2}-$ $\mathrm{OR}^{2}$. 


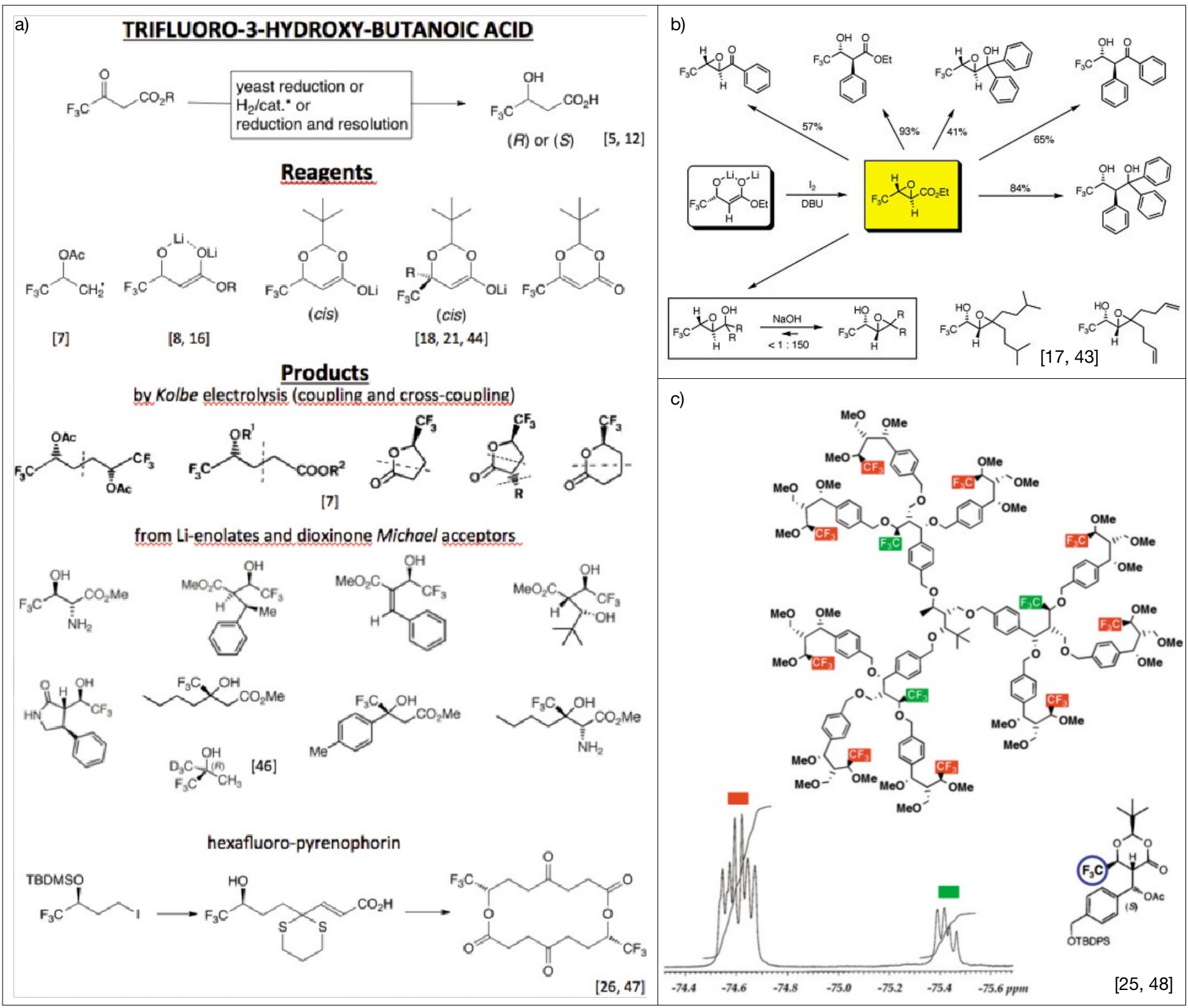

Fig. 7. a) (R)- and (S)-Trifluoro-3-hydroxy-butanoic acid and products derived thereof through radical, enolate and Michael acceptor intermediates. $\mathrm{F}_{3}$-Acetoacetic ester is a cheap industrial material. The resolution of its reduction product was achieved with 1-phenethyl-amine. Kolbe Electrolysis of the acetoxy-acid alone or with excess malonic or succinic half-ester produces the 1,4-diol-diacetate and the $\gamma$ - and $\delta$-hydroxy-acid derivatives, respectively. Amination, alkylation, aldol addition/condensation, and Michael addition (to nitrostyrene), as well as Cu-catalyzed Michael addition to the 2-tBu-6- $\mathrm{F}_{3} \mathrm{C}-5$-dioxin-4-one lead to the products shown. In contrast to the parent compound, hexafluoro-pyrenophorin shows no antibiotic activity. b) Preparation of trifluoromethyl-glycidic ester by iodination of the lithioxy-lithium enolate of the $\beta$-hydroxyester and cyclization. Reactions of the epoxyester with various nucleophiles and Payne rearrangement under basic conditions (in this process, the less acidic epoxy-alcohol is converted to the more acidic one). Dramatic differences of reactivities and properties, as compared to non-fluorinated analogs, have been reported in these investigations. $\left.{ }^{[17]} \mathrm{C}\right) \mathrm{A}$ chiral dendrimer consisting of triol ether moieties prepared by addition of the trifluoromethyl-substituted dioxanone Li-enolate to pivalaldehyde (center part) and to 4-TBDPS-O- $\mathrm{CH}_{2}$-benzaldehyde (branching points). The inner three and the outer nine $\mathrm{F}_{3} \mathrm{C}$-groups are all constitutionally heterotopic, and their ${ }^{19} \mathrm{~F}-\mathrm{NMR}$ signals are, at least partially, resolved (four of the expected six signals are seen for the inner and eight of the maximum 18 for the outer $\mathrm{F}_{3} \mathrm{C}$ groups). ${ }^{[25,48]}$

corporation of a fluoro-substituent in the 4-position (Fig. 8a), to see whether the thus increased acidity and reduced nucleophilicity of the neighboring $\mathrm{OH}$-group would lead to increased stability and/or activity of the immunosuppressive cycloundecapeptide; the activity in three standard tests was only slightly higher than that of CS A itself, and the stability in vivo was actually never tested. ${ }^{[61]}$ - Leucine was converted to a possible dipeptide isostere (5-amino-4,4difluoro-7-methyl-octanoic acid, Fig. 8b).

Most efforts were devoted to the ste- reospecific preparation of $\alpha$-fluoro- and $\alpha, \alpha$-difluoro- $\beta$-amino acids (Fig. $8 b$ ) and their incorporation into $\beta$-peptides. Since $\alpha$-peptides with fluoro-substituents on back-bone positions are non-existent the $\beta$-peptides containing, or consisting entirely of, fluoro-amino-acid residues allowed us to study, for the first time, the effect of fluoro-groups on peptidic secondary structures. It turned out that the conformational preference of $\alpha$-fluoro-amide groups, alluded to in Fig. 1a, is strong enough to stabilize or destabilize helices or turns (by incorporation of a single (!) fluoro-aminoacid residue, see Fig. 8c).

\section{Non-rationalized Reactivities and Structural Effects Observed with Organofluorine Compounds}

Again and again it happened that the chemical behavior of fluoro-derivatives completely baffled us. At first sight, the unexpected result of an experiment can be frustrating, even more so, when we have 


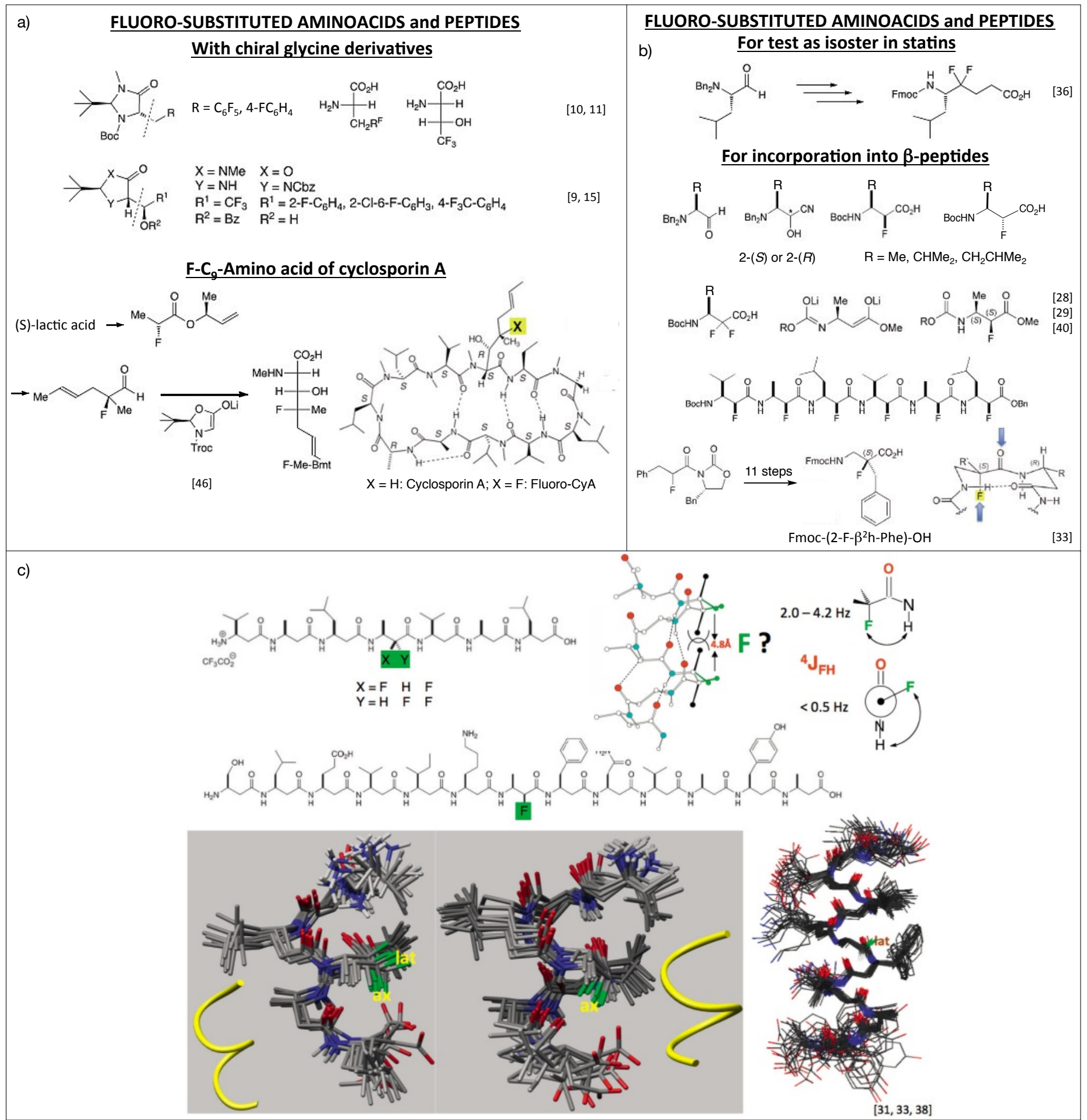

Fig. 8. a) F-Containing $\alpha$-amino acids by alkylation or hydroxyalkylation of enantiopure imidazolidinone and oxazolidinone enolates and hydrolytic cleavage of the primary products (top). Hitherto unpublished synthesis of F-Bmt for incorporation into cyclosporine (bottom); (R)-fluoro-propanoic acid was allylated by Claisen rearrangement of its (S)-2-but-3-enyl ester and the product reduced to an aldehyde, to which the Troc-oxazolidinone enolate was added diastereoselectively with formation of the threonine-type substructure of Bmt. ${ }^{[4]}$ As with other Bmt analogs, incorporation of the F-Bmt into Cy A was achieved by 'offering' it to Cy A-producing microorganisms. ${ }^{[6]]} b$ ) Preparation of a $\delta$ - and of a series of $\beta$-amino acids carrying fluorine in the $\gamma$ - and $\alpha$-position, respectively, and synthesis of $\beta$-peptides containing a single fluoro-substituent (cf. Fig. $8 c)$ or a fluorine atom in every residue. From alanine, valine and leucine the Reetz aldehydes were prepared and converted to either $(S, S)$ - or $(R, S)$-cyanohydrins; the hydroxyesters resulting from a Pinner-type methanolysis were then treated with DAST to give (with retention of configuration) 3-amino-2-fluoro-substituted esters, and finally $N$-Boc-protected acids were prepared for peptide synthesis in solution. Alternatively an $(S, S)$-derivative of $\beta^{3} h$-alanine is also accessible by diastereoselective fluorination with $\left(\mathrm{PhSO}_{2}\right)_{2} \mathrm{NF}$ of the doubly lithiated Boc- or Cbz-protected methylester. Geminal difluoro-amino acids were prepared by DAST treatment of the corresponding carbonyl compounds ('keto'-amino acids). c) Incorporation of (S,S)- or (R,S)-2-fluoroand of (S)-2,2-difluoro-3-amino-acid residues in the center position of a hepta- and a trideca- $\beta$-peptide and NMR structure determination in MeOH. In the $3_{14}$-helix of $\beta^{3}$-peptides each tetrahedral $\left(\mathrm{sp}^{3}\right)$ center of the backbone has an axial and a lateral position for substituents. The distance between two such centers lying on top of each other is ca. $4.8 \AA$, enough for two axial hydrogen substituents (the sum of two covalent and two van-der-Waals radii for $\mathrm{C}-\mathrm{H} \cdots \mathrm{H}-\mathrm{C}$ is ca. $4.4 \AA$ ). An axial Me group is forbidden, ${ }^{[62]}$ how about a fluorine (C-H $\cdots \cdot \mathrm{F}-\mathrm{C}$ distance $\left.>5 \AA\right)$ ? The NMR analysis of the corresponding peptide structures indicates that an axial $F$ is possible in the helix of the heptapeptide while a lateral $F$ is not (the preferred fluoroamide conformation 'breaks' the helix!). It takes the cooperativity of the tridecapeptide to force a fluorine atom into the lateral position, with the unfavorable fluoroamide conformation. Like almost all our $\beta$-peptide NMR structures this analysis is due to a wonderful collaboration with $B$. Jaun. ${ }^{[31,33,38]}$ 
no rationale to offer. On the other hand, a central element of science is the discovery of new facts, in chemistry particularly the "creation of new objects", as Berthelot put it in his definition of chemistry. [63] Thus, there was always a mixture of frustration and excitement (fluster, flutter) when a coworker reported an unexpected result, which was hard to understand or could not be rationalized at all - and this was the case especially frequently with fluorosubstrates. This is why our group started using the term "flustrate", ${ }^{[14]}$ which Roald Hoffmann appreciated - for poetic and linguistic reasons. In Figs. 9a and b just a few examples are collected of non-rationalized results or effects we experienced with fluorine derivatives over the years.

Thus, $\beta$-fluoro-nitroalkanes are poor substrates in classical base-catalyzed nitroaldol reactions (because of HF elimination: $\mathrm{F}^{-}$is a good leaving group only in protic solvents). We found that di- and trifluoronitroalkanes can be doubly lithiated or silylated with butyllithiums or with DMAP/ $\mathrm{ClSiR}_{3}$ without loss of fluoride. On the other hand, treatment of $\mathrm{F}_{3} \mathrm{CCH}\left(\mathrm{NO}_{2}\right) \mathrm{CH}_{3}$ with the silylating reagents $\mathrm{Me}_{2} \mathrm{NCO}_{2} \mathrm{SiR}_{3}$ led to complete loss of all three fluorine atoms with formation of 1,1-bisdimethylamino-2-nitro-propene (Fig. 9a, a)). A total change of mechanism must occur when the $\mathrm{CH}_{3}$-group of the dioxinone Michael acceptor shown in Fig. 9a, b) is replaced by $\mathrm{F}_{3} \mathrm{C}$ in the $\mathrm{Cu}(\mathrm{I})$-mediated addition of benzyl Grignard reagent! No clue is offered to explain the effect of a single fluorine atom in the Michael addition of $\mathrm{N}$-Me-indol to cinnamaldehyde catalyzed by the so-called MacMillan generation I organocatalyst (Fig. 9a, c)). The 'transacetalization' of an

Fig. 9. a) Some unexpected reactions of fluoroderivatives. aa) No LiF- or $\mathrm{R}_{3} \mathrm{SiF}$-elimination from 1,1,1-trifluoro-2-nitro-propane with BuLi or DMAP, but complete loss of all three fluorines with $\mathrm{Me}_{2} \mathrm{NCO}_{2} \mathrm{SiMe}_{3}$ in a series of $\beta$-eliminations/conjugate additions. ab) transBenzylation of the $\mathrm{CH}_{3}$-substituted dioxinone and coupling in the para-position with the $\mathrm{F}_{3} \mathrm{C}$ analog $(\mathrm{BnMgCl} / \mathrm{CuCl})$. ac) Reversal of the stereochemical course of an organocatalytic reaction with cis- and trans-5-benzyl-2-fluoromethyl-2,3-dimethyl-imidazolidinone. ad) Reaction in the solid state of rac-tBu-trifluoromethyldioxanone to form a 12-membered ring; the enantiopure cis- and trans-forms and the $\mathrm{CH}_{3}$-analogs are stable compounds of dioxanone structure. b) Octreotide (Sandostatin ${ }^{\circledR}$ ), the corresponding dithiol and $\mathrm{F}_{3} \mathrm{C}$-derivatives obtained with the Togni reagent. The strong Cotton effect of octreotide (blue CD curve) disappears upon trifluoromethylation in 2-position of the indolyl group (red CD curve). Concomitantly, a dynamic NMR analysis reveals that the rigid backbone conformation of octreotide becomes highly flexible by introduction of the $\mathrm{F}_{3} \mathrm{C}$-group.

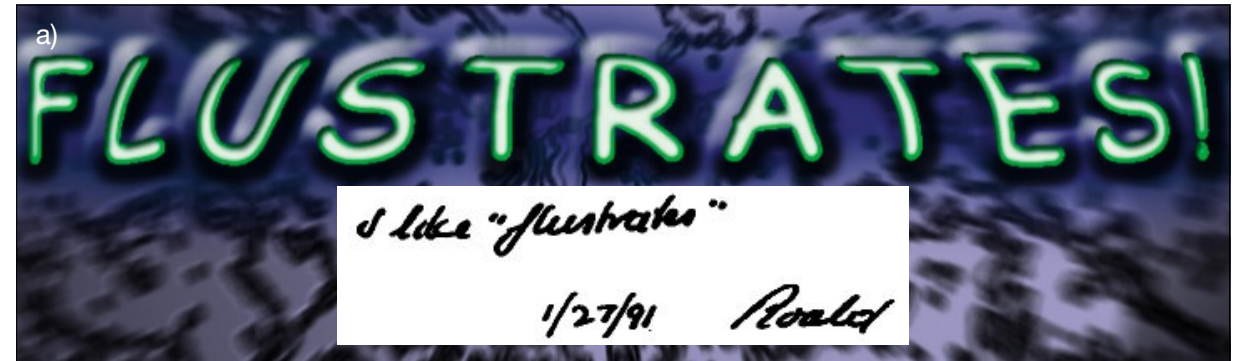

a) NON-RATIONALIZED REACTIONS OF FLUORINE-DERIVATIVES aa)

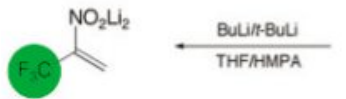

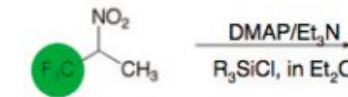
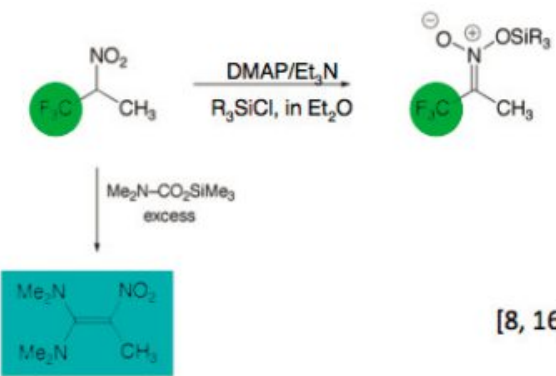

$[8,16]$

ab)

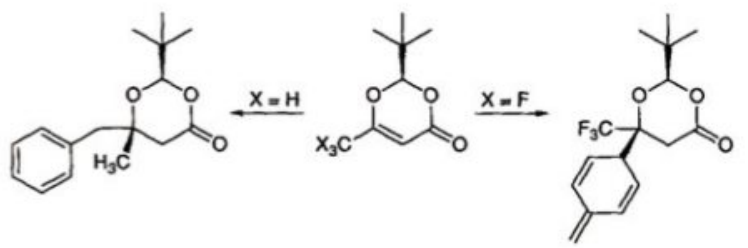

$[18,21,44]$

ac)

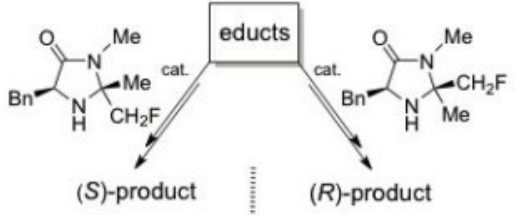

ad)

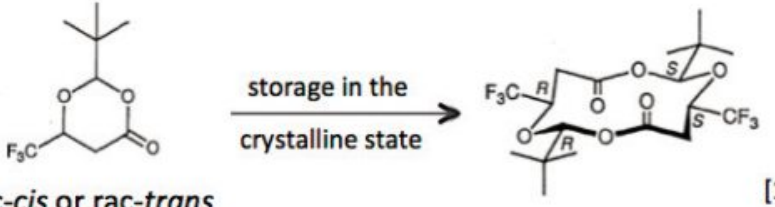

[13]
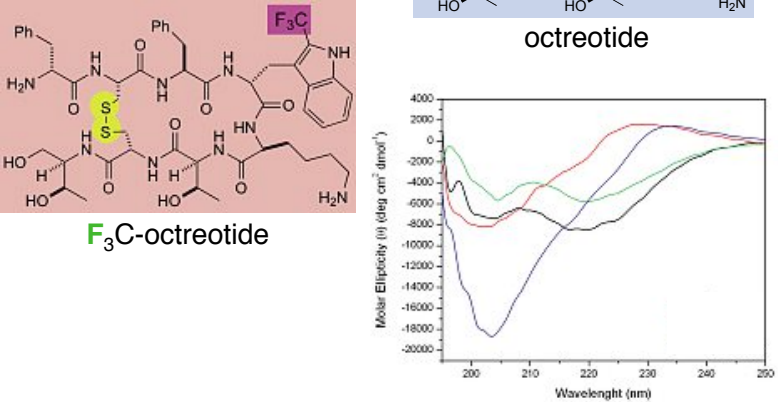

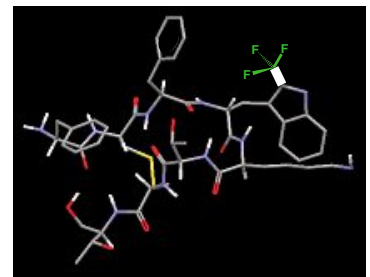

X-ray of octreotide with graphical attachment of $\mathrm{CF}_{3}$

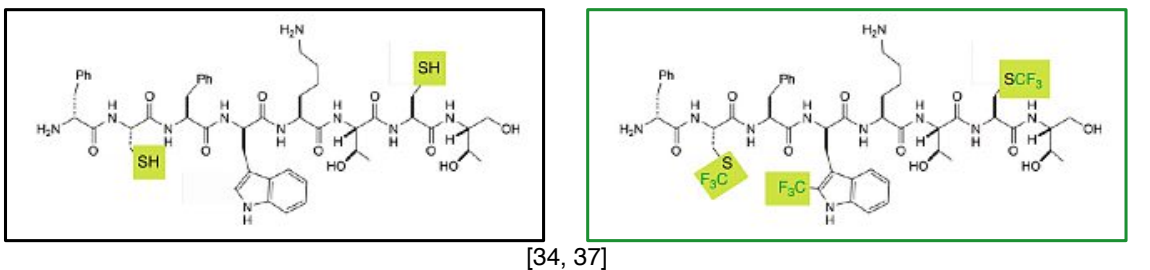


$\mathrm{F}_{3} \mathrm{C}$-substituted dioxanone in the crystalline state is yet another example causing flustration (Fig. 9a, d)). Finally, laymen [34] and specialists ${ }^{[37]}$ are equally surprised about the backbone flexibilization of the octreotide backbone by introduction of an $\mathrm{F}_{3} \mathrm{C}$-group in the tryptophane side chain (Fig. 9b) - albeit a comparison within the $\mathrm{H}_{3} \mathrm{C}$-analog has not been made as yet.

It remains for us to cite a doggerel about fluorine by V. O. J. Newton: ${ }^{[64]}$

\section{The ultimate combiner}

Fervid Fluorine, though just Nine

Knows her aim in life: combine!

In fact, of things that like to mingle,

None's less likely to stay single.

\section{Acknowledgements}

I thank all the coworkers and collaborators, who took the risk of flustration with me over the years; their names are given in the list of references. ${ }^{[2-48]}$ I ask those, whose work was not published, to forgive me, but also those, whose results were published 'only' in German, and thus remained almost unnoticed in the literature. Finally, my special thank goes to Albert K. Beck for his F-contributions and for his help in producing the manuscript of this autobiography.

\section{Received: March 25, 2014}

[1] M. Schlosser, ' $\mathrm{CF}_{3}$-Bearing Aromatic and Heterocyclic Building Blocks', Angew. Chem. 2006, 118, 5558; Angew. Chem. Int. Ed. 2006, 45,5432 ; M. Schlosser, 'The $2 \times 3$-Toolbox of Organometallic Methods for Regiochemically Exhaustive Functionalization', Angew. Chem. 2005, 117, 380; Angew. Chem. Int. Ed. 2005, 44, 376; F. Leroux, P. Jeschke, M. Schlosser, ' $\alpha$-Fluorinated Ethers, Thioethers, and Amines: Anomerically Biased Species', Chem. Rev. 2005, 105, 827; M. Schlosser, 'Introduction of Fluorine into Organic Molecules: Why and How', Tetrahedron 1978, 34, 3.

[2] R. Schlecker, U. Henkel, D. Seebach, 'Über den Mechanismus des Zerfalls perheterosubstituierter Ethane. Hexakis(alkylthio)- und Tetrakis(methylthio)bis(trimethylsilyl)-ethane', Chem. Ber. 1977, 110, 2880.

[3] B. Weidmann, L. Widler, A. G. Olivero, C. D. Maycock, D. Seebach, 'Selectivities in the Reactions of Alkyl-, Aryl- and Heterosubstituted Organotitanium Compounds', Helv. Chim. Acta 1981, 64, 357.

[4] C. Nájera, M. Yus, R. Hässig, D. Seebach, 'Fluoro(phenylsulfinyl)methyllithium. Note on the ${ }^{13} \mathrm{C}$-NMR Spectrum of a Fluorocarbenoid', Helv. Chim. Acta 1984, 67, 1100.

[5] D. Seebach, P. Renaud, W. B. Schweizer, M. F. Züger, M.-J. Brienne, 'Preparation by Yeast Reduction and Determination of the Sense of Chirality of Enantiomerically Pure Ethyl (-)-4,4,4-Trichloro-3-hydroxy- and (+)-4,4,4-Trifluoro-3-hydroxybutanoate', Helv. Chim. Acta 1984, 67, 1843.

[6] D. Seebach, A. K. Beck, S. Roggo, A. Wonnacott, 'Enantioselektive Addition von Arylgruppen an aromatische Aldehyde mit AryltitanBinaphthol-Derivaten', Chem. Ber. 1985, 118, 3673; B. Weber, D. Seebach, 'Ti-TADDOLateCatalyzed, Highly Enantioselective Addition of Alkyl- and Aryl-Titanium Derivatives to Aldehydes', Tetrahedron 1994, 50, 7473.
[7] D. Seebach, P. Renaud, 'Chirale Synthesebausteine durch Kolbe-Elektrolyse enantiomerenreiner $\beta$-Hydroxy-carbonsäurederivate. $(R)$ und $(S)$-Methyl- sowie $(R)$-Trifluormethyl- $\gamma$ butyrolactone und $-\delta$-valerolactone', Helv. Chim. Acta 1985, 68, 2342.

[8] D. Seebach, A. K. Beck, P. Renaud, 'Di- and Trifluoro-Substituted Dilithium Compounds for Organic Syntheses', Angew. Chem. 1986, 98, 96; Angew. Chem. Int. Ed. Engl. 1986, 25, 98.

[9] D. Seebach, E. Juaristi, D. D. Miller, C. Schickli, T. Weber, 'Addition of Chiral Glycine, Methionine, and Vinylglycine Enolate Derivatives to Aldehydes and Ketones in the Preparation of Enantiomerically Pure $\alpha$-Amino$\beta$-hydroxy Acids', Helv. Chim. Acta 1987, 70, 237.

[10] Robert Fitzi, Dieter Seebach, 'Resolution and Use in $\alpha$-Amino Acid Synthesis of Imidazolidinone Glycine Derivatives', Tetrahedron 1988, 44, 5277.

[11] D. Seebach, E. Dziadulewicz, L. Behrendt, S. Cantoreggi, R. Fitzi, 'Synthesis of Nonproteinogenic $(R)$ - or $(S)$-Amino Acids. Analogues of Phenylalanine, Isotopically Labelled and Cyclic Amino Acids from tert-Butyl 2-(tert-Butyl)-3-methyl-4-oxo-1imidazolidinecarboxylate (Boc-BMI)', Liebigs Ann. Chem. 1989, 1215.

[12] M. Acs, C. von dem Bussche, D. Seebach, 'An Efficient Method of Preparing $(R)$ - and $(S)-4,4,4$ Trifluoro-3-hydroxybutanoic Acid: Resolution with $(R)$ - or $(S)$-1-Phenylethylamine', Chimia 1990, 44,90 .

[13] A. K. Beck, M. Gautschi, D. Seebach, 'Die Geschichte einer Acetalisierung und die überraschende Dimerisierung eines 1,3-Dioxan4-ons zu einem Zwölfring [2-(tert-Butyl)6-(trifluoromethyl)-1,3-dioxan-4-on und 2,8-D(tert-butyl)-6,12-bis(trifluoromethyl)$1,3,7,9$-tetraox acyclodecan-4, 10 -dion aus rac-, $(R)-$ und $(S)-4,4,4-$ Trifluoro-3hydroxybutansäure und Pivalaldehyd]', Chimia 1990, 44, 291.

[14] D. Seebach, 'Organic Synthesis - where now?', Angew. Chem. 1990, 102, 1363; Angew. Chem. Int. Ed. Engl. 1990, 29, 1320.

[15] D. Blaser, D. Seebach, 'Benzyl $(R)$ - and $(S)$ 2-tert-Butyl-5-oxo-oxazolidine-3-carboxylate for Convenient Preparation of D- and L-Threonine Analogs from Aldehydes', Liebigs Ann. Chem. 1991, 1067.

[16] A. K. Beck, D. Seebach, 'Aldol- und Michael-Additionen fluorierter Nitroalkane an Aldehyde, Ketone und $\alpha, \beta$-ungesättigte Carbonylverbindungen', Chem. Ber. 1991, 124, 2897.

[17] C. von dem Bussche-Hünnefeld, D. Seebach, 'Herstellung und Umsetzungen von $(R, R)$ - und $(S, S)$-3-Trifluormethyloxiran-2-carbonsäureethylester, einem vielseitigen, leicht zugänglichen $\mathrm{CF}_{3}$-haltigen Synthesebaustein', Chem. Ber. 1992, 125, 1273.

[18] M. Gautschi, D. Seebach, 'Synthesis of $(R)$ - and (S)-2-tert-Butyl-6-trifluoromethyl-1,3-dioxin4-ones, Transformations into 3-Hydroxy-3(trifluoromethyl)alkanoates, and Surprising Differences in the Reactivity of $\mathrm{CH}$,- and CF,Substituted Compounds', Angew. Chem. 1992, 104, 1061; Angew. Chem. Int. Ed. Engl. 1992, 31,1083 .

[19] C. von dem Bussche-Hünnefeld, C. Cescato, D. Seebach, 'Ergiebige Herstellung von $(R)$ - und $(S)$-3,3,3-Trifluormilchsäure und von $(R)$ - und (S)-(Trifluormethyl)oxiran', Chem. Ber. 1992, $125,2795$.

[20] J.-M. Lapierre, M. Gautschi, G. Greiveldinger, D. Seebach, 'Reaction of 6-( $\left(\mathrm{CF}_{3}\right)$ - and 6-( $\left.\mathrm{CH}_{3}\right)$ 2-(tert-Butyl)-1,3-dioxan-4-one Li-Enolate with Two Equivalents of an Aldehyde - Unusual Reorganizations of Aldolates', Chem. Ber. 1993, 126, 2739.
[21] M. Gautschi, W. B. Schweizer, D. Seebach, 'In 2und 3-Stellung verzweigte, enantiomerenreine 4,4,4-Trifluor-3-hydroxy-buttersäure-Derivate aus 6-Trifluormethyl-1,3-dioxan- und -dioxin4-onen', Chem. Ber. 1994, 127, 565.

[22] R. E. Marti, J. Heinzer, D. Seebach, 'Preparation and Reactions of Silyl Nitronates Derived from 2,2,2-Trifluoronitroethane. Diastereoselective Synthesis of Trifluoromethyl- Substituted Aminoethanols and -propanols', Liebigs Ann. 1995, 1193.

[23] A. R. Sting, D. Seebach, 'Synthesis of $(2 R), 3 S)$ or (2S,3R)-2-Amino-3-trifluoromethyl-3-hydroxyalkanoic Acid Derivatives (Threonine and allo-Threonine Analogs) from Enantiopure 4,4,4-Trifluoro-3-hydroxybutanoic Acid', Tetrahedron 1996, 52, 279.

[24] S. P. Götzö, D. Seebach, 'Preparation of $(R)$ - and (S)-3-Hydroxy-2-(trifluoromethyl) propionic Acid by Resolution with $(R, R)$ - and $(S, S)$-2-Amino-1-phenylpropane-1,3-diol', Chimia 1996, 50, 20.

[25] G. Greiveldinger, D. Seebach, 'SecondGeneration Trifluoromethyl-Substituted Chiral Dendrimers Containing Triply Branched Building Blocks: $\mathrm{CF}_{3}$ as Sensitive NMR Probe for 'Remote' Diastereotopicity', Helv. Chim. Acta 1998, 81, 1003.

[26] S. P. Götzö, D. Seebach, J.-J. Sanglier, 'EPC Syntheses of Trifluorocitronellol and of Hexafluoropyrenophorin - A Comparison of Their Physiological Properties with the Nonfluorinated Analogs', Eur. J. Org. Chem. 1999, 2533.

[27] D. Seebach, T. Sifferlen, D. J. Bierbaum, M. Rueping, B. Jaun, B. Schweizer, J. Schaefer, A. K. Mehta, R. D. O'Connor, B. H. Meier, M. Ernst, A. Glättli, 'Isotopically Labelled and Unlabelled $\beta$-Peptides with Geminal Dimethyl Substitution in 2-Position of Each Residue: Synthesis and NMR Investigation in Solution and in the Solid State', Helv. Chim. Acta 2002, $85,2877$.

[28] F. Gessier, C. Noti, M. Rueping, D. Seebach, 'Synthesis and CD-Spectra of Fluorine- and Hydroxy-Substituted $\beta$-Peptides', Helv. Chim. Acta 2003, 86, 1862.

[29] D. F. Hook, F. Gessier, C. Noti, P. Kast, D. Seebach, 'Probing the Proteolytic Stability of bPeptides Containing $\alpha$-Fluoro- and $\alpha$-Hydroxyß-Amino Acids', ChemBioChem 2004, 5, 691.

[30] M. Rueping, M. Albert, D. Seebach, 'On the Structure of PHB (=Poly $[(R)-3$ hydroxybutanoic Acid]) in Phospholipid Bilayers: Preparation of TrifluoromethylLabeled Oligo[ $(R)$-3-hydroxybutanoic Acid] Derivatives', Helv. Chim. Acta 2004, 87, 2473.

[31] R. I. Mathad, F. Gessier, D. Seebach, B. Jaun, 'The Effect of Backbone-Heteroatom Substitution on the Folding of Peptides A Single Fluorine Substituent Prevents a $\beta$-Heptapetide from Folding into a 3 -Helix (NMR Analysis)', Helv. Chim. Acta 2005, 88, 266.

[32] O. Flögel, J. D. C. Codée, D. Seebach, P. H. Seeberger, 'Microreactor Synthesis of $\beta$-Peptides', Angew. Chem. 2006, 118, 7157; Angew. Chem. Int. Ed. 2006, 45, 7000.

[33] R. I. Mathad, B. Jaun, O. Flögel, J. Gardiner, M. Löweneck, J. D. C. Codée, P. H. Seeberger, D. Seebach, M. K. Edmonds, F. H. M. Graichen, A. D. Abell, 'NMR-Solution Structures of Fluoro-

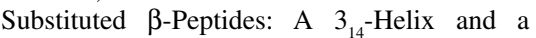
Hairpin Turn. The First Case of a $90^{\circ} \mathrm{O}=\mathrm{C}-\mathrm{C}-\mathrm{F}$ Dihedral Angle in an $\alpha$-Fluoro Amide Group', Helv. Chim. Acta 2007, 90, 2251.

[34] S. Capone, I. Kieltsch, O. Flögel, G. Lelais, A. Togni, D. Seebach, 'Electrophilic S-Trifluoromethylation of Cysteine Side Chains in $\alpha$ - and $\beta$-Peptides and Isolation of Trifluoromethylated Sandostatin $^{\circledR}$ (Octreotide) Derivatives', Helv. Chim. Acta 2008, 91, 2035. 
[35] U. Grošelj, D. Seebach, D. M. Badine, W. B. Schweizer, A. K. Beck, I. Krossing, P. Klose, Y. Hayashi, T. Uchimaru, 'Structures of the Reactive Intermediates in Organocatalysis with Diarylprolinol Ethers', Helv. Chim. Acta 2009. 92, 1225.

[36] G. Deniau, D. Seebach, 'Preparation of $N$-Fmoc-Protected $(S)$-5-Amino-4,4-difluoro7-methyloctanoic Acid, a Possible Dipeptide Isostere', Helv. Chim. Acta 2009, 92, 1720.

[37] D. Seebach, H. Widmer, S. Capone, R. Ernst, T. Bremi, I. Kieltsch, A. Togni, D. Monna, D. Langenegger, D. Hoyer, 'NMR-Solution Structures and Affinities for the Human Somatostatin G-Protein-Coupled Receptors hsst $_{1-5}$ of $\mathrm{CF}_{3}$ Derivatives of Sandostatin ${ }^{\circledast}$ (Octreotide)', Helv. Chim. Acta 2009, 92, 2577.

[38] B. Jaun, D. Seebach, R. I. Mathad, 'Note: Helix or no Helix of $\beta$-Peptides Containing $\beta^{3} \mathrm{hAla}(\alpha \mathrm{F})$-Residues?', Helv. Chim. Acta 2011 $94,355$.

[39] L. K. Charkoudian, C. W. Liu, S. Capone, S. Kapur, D. E. Cane, A. Togni, D. Seebach, C. Khosla, 'Probing the interactions of an acyl carrier protein domain from the 6-deoxyerythronolide B synthase', Protein Science 2011, 20 , 1244.

[40] T. Yoshinari, F. Gessier, C. Noti, A. K. Beck, D. Seebach, 'Stereoselective Preparation of 3-Amino-2-fluoro Carboxylic Acid Derivatives, and Their Incorporation in Tetrahydropyrimidin4(1H)-ones, and in Open-Chain and Cyclic ß-Peptides', Helv. Chim. Acta 2011, 94, 1908.

[41] U. Grošelj, Č. Podlipnik, J. Bezenšek, J. Svete, B. Stanovnik, D. Seebach, 'Reversal of the Stereochemical Course of 1-Methyl- $1 H$-indole Addition to Cinnamaldehyde with cis-5-Benzyl(2-fluoromethyl)-2,3-dimethylimidazolidin4-ones as Catalysts - a Puzzling 'Fluorine Effect", Helv. Chim. Acta 2013, 95, 1815.

[42] P. Renaud, 'Chirale nicht racemische Synthesebausteine durch elektrochemische Oxidation von Carbonsäuren', Diss. ETH Nr. $8155, \mathbf{1 9 8 6}, 89$.

[43] C. Von dem Bussche-Hünnefeld, 'Enantiomerenreine trifluormethyl-substituierte $\mathrm{C}_{3}$ und $\mathrm{C}_{4}$-Bausteine für die Organische Synthese'; Diss. ETH Nr. 9839, 1992.

[44] M. Gautschi, 'Neue enantiomerenreine trifluormethyl-substituierte 3-HydroxycarbonsäureDerivate', Diss. ETH Nr. 10'279, 1993.

[45] R. E. Marti, 'Silylnitronate von Trifluornitroalkanen (als Synthesebausteine) und Polymergebundene TADDOLe (Liganden für chirale Lewis-Säuren)', Diss. ETH Nr. 11'571, 1996.

[46] A. R. Sting, 'Stereoselektive Synthese von in 4-Stellung fluorierten Analogen der einzigartigen Aminosäure MeBmt (N-Methyl-(4R)-

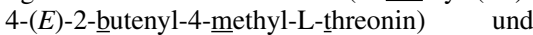

Herstellung von ( $R$ )-2-Methyl-3,3,3-trideutero1,1,1-trifluorpropan-2-ol', Diss. ETH $\mathrm{Nr}$. 11 '669, 1996.

[47] S. P. Götzö, 'Synthesen von $(S, S)$-Hexafluorpyrenophorin und $(R)$-Trifluorcitronellol und Enantiomerenreine 3-Hydroxy-2-trifluormethylpropionsäure - ein $\mathrm{C}_{4}$-Baustein für die Organische Synthese', Diss. ETH Nr. 12'349, 1997.

[48] G. Greiveldinger Guy, 'Synthese von chiralen Dendrimeren mit dreifach verzweigenden chiralen Bausteinen und deren fluorierten Analoga: Ein interessanter Fall von Diastereoselektivität und Untersuchungen mit Raster-Tunnelmikroskopie', Diss. ETH Nr. $12 ’ 488,1997$.

[49] For TADDOLs in organofluorine chemistry see: A. Bertogg, L. Hintermann, D. P. Huber, M. Perseghini, M. Sanna, 'Substrate Range of the Titanium TADDOLate Catalyzed Asymmetric Fluorination of Activated Carbonyl Compounds', A. Togni, Helv. Chim. Acta 2012 95, 353; and N. Santschi, A. Togni, Chimia 2014, $68, \mathrm{xxx}$.

[50] J. J. Irwin, T.-K. Ha, J. D. Dunitz, Helv. Chim Acta 1990, 73, 1805; L. E. Zimmer, C. Sparr, R. Gilmour, 'Fluorine Conformational Effects in Organocatalysis: An Emerging Strategy for Molecular Design', Angew. Chem. 2011, 123, 12062; Angew. Chem. Int. Ed. 2011, 50, 11860.

[51] I. J. Bruno, J. C. Cole, J. P. M. Lommerse, R. S. Rowland, R. Taylor, M. L. Verdonk, J. Comput. Aided Mol. Des. 1997, 11, 525.

[52] I thank J. D. Dunitz and W. B. Schweizer for allowing me to show these unpublished Figures herein.

[53] A. J. Kirby 'The Anomeric Effect and Related Stereoelectronic Effects at Oxygen', Springer, Berlin, 1983; A. J. Kirby, 'Stereoelectronic Effects' Oxford University Press, Oxford, 1996; H. B. Bürgi, J. D. Dunitz, 'From Crystal Statistics to Chemical Dynamics', Acc. Chem. Res. 1984, 16, 153

[54] J. D. Dunitz, R. Taylor, 'Organic Fluorine Hardly Ever Accepts Hydrogen Bonds', Chem. Eur. J. 1997, 3, 89; J. D. Dunitz, 'Organic Fluorine: Odd Man Out', ChemBioChem 2004, 5,614 .

[55] 'Handbook of Fluorous Chemistry', Eds. J. A. Gladysz, D. P. Curran, I. T. Horvath, Wiley$\mathrm{VCH}$, Weinheim, 2004

[56] J. D. Dunitz, A. Gavezzotti, W. B. Schweizer, Helv. Chim. Acta 2003, 86, 4073.

[57] B. Weidmann, D. Seebach, 'Organometallic Compounds of Titanium and Zirconium as Selective Nucleophilic Reagents in Organic Synthesis', Angew. Chem. 1983, 95, 12; Angew. Chem. Int. Ed. Engl. 1983, 22, 31; D. Seebach, B. Weidmann, L. Widler, 'Titanium and Zirconium Derivatives in Organic Synthesis.
A Review with Procedures' Modern Synthetic Methods 1983, Vol. 3, Ed. R. Scheffold, Salle + Sauerländer (Aarau, Switzerland) and J. Wiley and Sons (New York, USA), 1983, pp. 217353; C. Betschart, D. Seebach, 'Anwendungen niedervalenter Titan-Reagentien in der Organischen Synthese', Chimia 1989, 43, 39.

[58] D. Seebach, E. W. Colvin, F. Lehr, T. Weller, 'Nitroaliphatic Compounds - Ideal Intermediates in Organic Synthesis?', Chimia 1979, 33, 1 .

[59] D. Seebach, H.-O. Kalinowski, 'Enantiomerenreine Naturstoffe und Pharmaka aus billigen Vorläufern (Chiral Pool). - Zur Frage der chiral ökonomischen und ökologischen Totalsynthese', Nachr. Chem. Techn. 1976, 24, 415; D. Seebach, E. Hungerbühler, 'Syntheses of Enantiomerically Pure Compounds (EPCSyntheses). - Tartaric Acid, an Ideal Source of Chiral Building Blocks for Synthesis?' Modern Synthetic Methods 1980, Vol. 2, Ed. R. Scheffold, Salle + Sauerländer, Frankfurt/Aarau, 1980, pp. 91; D. Seebach, R. Imwinkelried, T. Weber, 'EPC Syntheses with C,C Bond Formation via Acetals and Enamines', Modern Synthetic Methods 1986, Vol. 4, Ed. R. Scheffold, Springer, Berlin, 1986, pp. 125; D. Seebach, S. Roggo, J. Zimmermann, 'BiologicalChemical Preparation of 3-Hydroxycarboxylic Acids and Their Use in EPC-Syntheses', in 'Stereochemistry of Organic and Bioorganic Transformations', Workshop Conferences Hoechst, Vol. 17, Eds. W. Bartmann, K. B. Sharpless, VCH, Weinheim, 1987, pp. 85; D. Seebach, A. R. Sting, M. Hoffmann, 'Self-Regeneration of Stereocenters (SRS) Applications, Limitations, and Abandonment of a Synthetic Principle', Angew. Chem. 1996, 108, 2880; Angew. Chem. Int. Ed. Engl. 1996, $35,2708$.

[60] A. Fischli, 'Using Enzymatic Transformations' Modern Synthetic Methods 1980, Vol. 2, Ed. R. Scheffold, Salle + Sauerländer, Frankfurt/ Aarau, 1980, pp. 269.

[61] R. Wenger (Sandoz), unpublished results.

[62] D. Seebach, P. E. Ciceri, M. Overhand, B. Jaun, D. Rigo, L. Oberer, U. Hommel, R. Amstutz, H. Widmer, Helv. Chim. Acta 1996, 79, 2043; D. Seebach, A. K. Beck, D. J. Bierbaum, 'The World of $\beta$ - and $\gamma$-Peptides Comprised of Homologated Proteinogenic Amino Acids and Other Components', Chem. Biodiv. 2004, 1, 1111.

[63] 'La chimie crée son object. Cette faculté créatrice, semblable à celle de l'art lui meme, la distingue essentiellement des sciences naturelles et historiques', M. Berthelot, 1860.

[64] V. C. J. Newton, 'Adam's Atoms: Making Light of the Elements', Viking Press, New York, 1965. 